\title{
Analysis of urban vulnerability as a tool for cultural heritage preservation. The cases of the medium-sized historical ensembles in Andalusia
}

\author{
Daniel Navas-Carrillo, Blanca del Espino Hidalgo, Juan-Andrés Rodríguez-Lora, \\ Teresa Pérez-Cano
}

\begin{abstract}
This paper presents the urban vulnerability assessment as a complementary resource in heritage preservation policies, through the analysis of the thirty-nine medium-sized cities that have been listed as Historical Ensemble in Andalusia (Spain). The research seeks to make a sequential approach that addresses, from the general -the conceptual framework on urban vulnerability and the characterization of the analysis sample- to the particular -the analysis of the socio-economic, socio-demographic or residential vulnerability applied to the intermediate scale which has not been in-deep studied yet-. For this, it proposes to adopt the methodology implemented by the Spanish Ministry of Development in the Atlas of Urban Vulnerability, providing a territorial lecture of the results. The study concludes that medium-sized cities do not present a level of vulnerability lower to the largest ones but detecting specific urban weaknesses that should be addressed to improve the response of these cities to heritage preservation.
\end{abstract}

Keywords: Baetica, cultural heritage, heritage conservation, intermediate cities, urban heritage, urban planning, vulnerability indicators

\section{Análisis de la vulnerabilidad urbana como herramienta de protección del Patrimonio Cultural. El caso de los Conjuntos Históricos en ciudades medias de Andalucía}

Resumen: Este artículo proponer evaluar la vulnerabilidad urbana como herramienta complementaria en las políticas de protección patrimonial mediante el análisis de las treinta y nueve ciudades medias declaradas Conjunto Histórico en Andalucía (España). La investigación intenta realizar una aproximación secuencial que aborda desde lo general, el marco conceptual sobre vulnerabilidad urbana y la caracterización de la muestra analizada, hasta lo concreto, el análisis de la vulnerabilidad socioeconómica, sociodemográfica y residencial en la escala intermedia, aún no estudiada en profundidad. Para ello, se propone adoptar la metodología implementada por el Ministerio de Fomento de España en el Atlas de Vulnerabilidad Urbana, proporcionando una lectura territorial de los resultados. El estudio concluye que las ciudades medias presentan un nivel de vulnerabilidad que no es inferior al de las de mayor tamaño, sin embargo, se identifican ciertas debilidades que deberán ser abordadas para mejorar la respuesta de estas ciudades a la conservación de su patrimonio.

Palabras clave: Baetica, ciudades intermedias, conservación patrimonial, indicadores de vulnerabilidad, patrimonio histórico, patrimonio urbano, planificación urbana

\section{Introduction}

\section{-Research definition}

This research proposes the inclusion of urban vulnerability assessment as an additional tool to be considered in the cultural heritage preservation policies. This hypothesis is based on the fact that, just as other external aggressors are taken into account in preventive conservation, the urban weaknesses should also be considered. The social, economic and residential weaknesses could reduce the capacity as a collective that cities have for preserving their heritage. This vision utterly implies an urban approach to the heritage of these cities, beyond the individual assessment of their cultural assets. This vision is also aligned with the change produced on the concept of heritage in recent decades. Attention has shifted from primarily objective considerations to the subject which demands it (Ruiz Castillo 2004: 18).

For this purpose, this work has adapted the methodology provided by the Spanish Ministry of Development in 
the Atlas of Urban Vulnerability. This methodology has been validated through its application in different urban contexts of the Spanish geography (Temes, 2014; Antón-Alonso \& Porcel, 2017; Rodríguez Peña, 2017; De Santiago Rodríguez, 2018). However, it has had a more significant impact on the analysis of the largest cities (Hernández Aja, Rodríguez Alonso, Rodríguez Suárez, 2018), finding a gap in the urban vulnerability analysis of the so-called medium-sized cities. In this sense, the research tries to identify the specific vulnerability issues of these intermediate urban scale, which differ from those of large cities.

Accurately, the weight of the system of medium-sized cities in the functional organisation is a fundamental characteristic that defines Andalusia; geographical framework analysed in this research. Andalusia is the most populous and the second-largest region in Spain, and approximately $60 \%$ of the autonomous territory is under the influence of a medium-sized city representing in population terms close to $15 \%$ of the inhabitants in the whole region. Besides, the historical relevance of the Andalusian medium-sized cities has been evidenced in national and international references (Madoz 1846-1850; Braun and Hogenberg 1572-1618). These circumstances have led to propose an analysis taking territorial organisation factors into account, according to the particular geographical characteristics, the historical evolution, the spatial planning or the specific legislation of each territory. In this sense, it seeks to provide a comparative study among different urban scales, which has not been developed yet.

On this regard, it is also important to mention that current territorial planning international strategies defend a polycentric model based on medium-sized cities. These cities not only favour a lower consumption of resources but also generate a more immediate relationship with the nearby rural environment. They contribute to avoid depopulation and acquire a key position in mitigating and adapting to climate change. Endowed with practically the same essential urban services as the large cities, they lack environmental problems, which ultimately means the increase of the population's quality of life (Del Espino Hidalgo \& Navas Carrillo, 2018:146).

\section{-Urban vulnerability and its repercussion on heritage preservation}

The term vulnerability applied to urban dimension arises during the cold war linked to the need for intervention in many eastern cities (Bankoff, 2019). In general terms, we can define it as a state of high exposure to certain risks and uncertainties, in combination with a reduced ability to protect or defend oneself against those risks and uncertainties and cope with their negative consequences (United Nations,
2003). Consequently, the term vulnerability has been widely accepted as the socio-economic risks that could affect society (Bankoff et al., 2004). Since this point of view, it has entered into a variety of disciplines such as disaster risk analysis (Wisner et al., 2004), natural hazard geographical research (Weichselgarnter, 2001; Cannon, 2008; Ran et al., 2020), climate change impacts (Fussel, 2007; Lankao \& Qin, 2011; Singh, 2017) or social-environmental approaches (Krellenberg et al., 2016). Thus, the vulnerability is currently related to resilience, a concept particularly extended in urban and regional planning in recent years (Cardoso, 2018; Faulkner, 2020). Terms that are in opposite sides (Godschalk, 2003), but should not be characterized as antonyms (Patel et al., 2020).

The vulnerability has also been applied to topics regarding social inclusion (Levron, 2010), such us, poverty, gender, class, caste, ethnicity, disability or elderly (Twigg, 2015). This perspective can be extended to urban studies. When done, it is inexorably linked to the application of preventive actions towards the inclusion of inhabitants (Ministerio de Fomento, 2012). It should be noted that their study has increased since 2008 due to the consequences of the economic crisis (Matesanz Parellada, 2017:29). Thus, the urban vulnerability can be understood as that process of unrest in cities produced by the combination of multiple dimensions of disadvantage, in which any hope of upward social mobility (to overcome their social condition of exclusion) is seen as extremely difficult to achieve. On the contrary, it carries a perception of insecurity and fear of the possibility of downward social mobility, of worsening of their current living conditions (Aguacil, 2006:161). However, it can be affirmed that the concept of urban vulnerability refers both to the increase of threats and risks that affect society and to the weakening of mechanisms to deal with such problems (Aguacil et al., 2014:18). In that sense, we can relate vulnerability to concepts largely addressed as the right to the city proposed by Henri Lefebvre (1968). Lately, it has been developed and reclaimed by social movements to fight against contemporary urban issues such as commodification and capitalism of the city, the decrease of social interaction and the rise of spatial inequalities and exclusion (Harvey, 2003).

As can be seen, urban vulnerability is, in short, directly related to the traditional dimensions of sustainability: economic balance, social equity and environmental resilience. However, a fourth dimension has been proposed as the centre or conceptual framework for the previous triangle: culture (Hawkes 2001). It is understood as to how our ancestors have adapted to the constant changes in environmental conditions throughout the cycles and have thus left a legacy to our times: cultural heritage, which must be understood as a source of inspiration, innovation and creativity 
to face current challenges. This approach evidences the need of including cultural heritage in sustainable development frameworks (UNESCO 2018), what necessarily must be connected to urban vulnerability assessment of the built cultural heritage, that is, the historical centres of the cities. Consequently, this work aims to evaluate urban vulnerability over a selection of urban areas - the historical centres and, particularly, the protected ones - of an urban category pointed out as an example of sustainability and equilibrium medium-sized cities.

\section{The system of medium-sized cities of Andalusia as a case study}

\section{- Definition of a medium-sized city}

Medium-sized cities have been considered from the European directives as to the urban category with the best qualities for urban-territorial sustainability (European Union 2011: VII), what has encouraged the increase of their protagonism in territorial planning and development strategies, as well as to in framework policies. In the second half of the 20th century, many countries of the European Union focused part of their development policies on the dynamization of mediumsized cities. The first attempts derive from the theory of the central places of Walter Christaller (1933), extended by Auguste Lösch (1940) and from the concept of the pole of development in the regional scope used by Perroux (1955). Hirschman (1958) would formulate a theoretical body to be used in territorial planning for the promotion of the later called intermediate cities.

Currently, their defence is based on the sustainability of a polycentric territorial model against metropolization processes (Vilagrasa 2000). In this sense, in recent years, this urban category has aroused particular interest in the quality of life it presents, as it lacks many of the environmental problems of large cities, as well as in the very scale of the city that makes it more humane and accessible. On the other hand, medium-sized cities favour a more rational use of resources, guaranteeing access to specialised goods and services in conditions like those carried out in large urban areas (Llop Torné and Hoeflich de Duque 2007: 10). As for their definition, it should not be done exclusively in demographic terms, but understood by their strategic position within the functional organisation of a nearby region or regional scope, and far from the synergies of the principal regional centres, as stated in the Unesco Report on Intermediate Cities (Bellet Sanfeliu and Llop Torné 1999). According to it, the concept of the medium-sized city goes beyond the mere intermediate position between the large metropolitan areas and the rural sphere. It is necessary to consider the socio-economic and cultural conditions of each territory, which will determine the different municipal roles, regardless of the number of inhabitants. For Bellet and Beltrão, (2009: 43), "mediumsized cities articulate the territory and function as reference centres for a more or less immediate territory".

In the case of Andalusia, they are officially recognised by the Regional Spatial Plan (approved by Decree $206 / 2006$, of 28 November), which proposes a hierarchical territorial structure - the System of Cities - distinguishing three categories: Regional Centres, Medium-sized Cities and Rural Areas. This classification has been made based on demographic size, diversity and dynamics of its economic base and functional weight. Although the size of a medium-sized city should not be measured in absolute terms, in Andalusian, it would correspond to populations between 100,000 and 15,000 inhabitants, coinciding with the hypothesis of Merinero and Lara (2010: 2).

\section{- Cultural heritage characterization of the Medium-sized cities of Andalusia}

This study follows the Andalusian Regional Spatial Plan, in Spanish Plan de Ordenación Territorial de Andalucía (Junta de Andalucía, 2006). This document includes a total of sixty-one medium-sized cities in the Andalusian geography [figure 1]. The research has selected those that have been or are in the process of being listed as Historical Ensemble. This classification means public recognition and legal protection of their heritage values as a whole. In the past, this responsibility exclusively corresponded to the Government of Spain. Currently, the Regional Government is also in charge to classify a city as Historical Ensemble.

The selected cities have been analysed according to their position in the territory. It has been necessary to distinguish between interior and coastal geographic domain due to the different evolution they have experienced during the $20^{\text {th }}$ century. Special mention requires coastal cities since their development has been mainly boosted by mass tourism since the 60s. Out of the forty medium-sized cities in inner Andalusia (Del Espino Hidalgo 2015: 62), twenty-six (65\%) have been listed as Historical Ensembles or are in process [table 1]. Besides, out of the twenty-one medium-sized cities located on the Andalusian coast (Navas-Carrillo et al., 2019: 250-251), thirteen (61.9\%) have been listed or are under study. In addition to the individual built heritage assets, this classification assesses the urban, spatial and landscape configuration of these thirty-nine cities analysed as a whole. International agencies as UNESCO also has recognised the heritage value of several of these medium-sized cities. For instance, Úbeda and Baeza (Jaen) are listed on the World Heritage List as "Renaissance Monumental Ensembles of Úbeda and Baeza" (UNESCO 2003: 121), or the "Antequera Dolmens Site" (UNESCO 2016: 223), located in the Province of Málaga. 


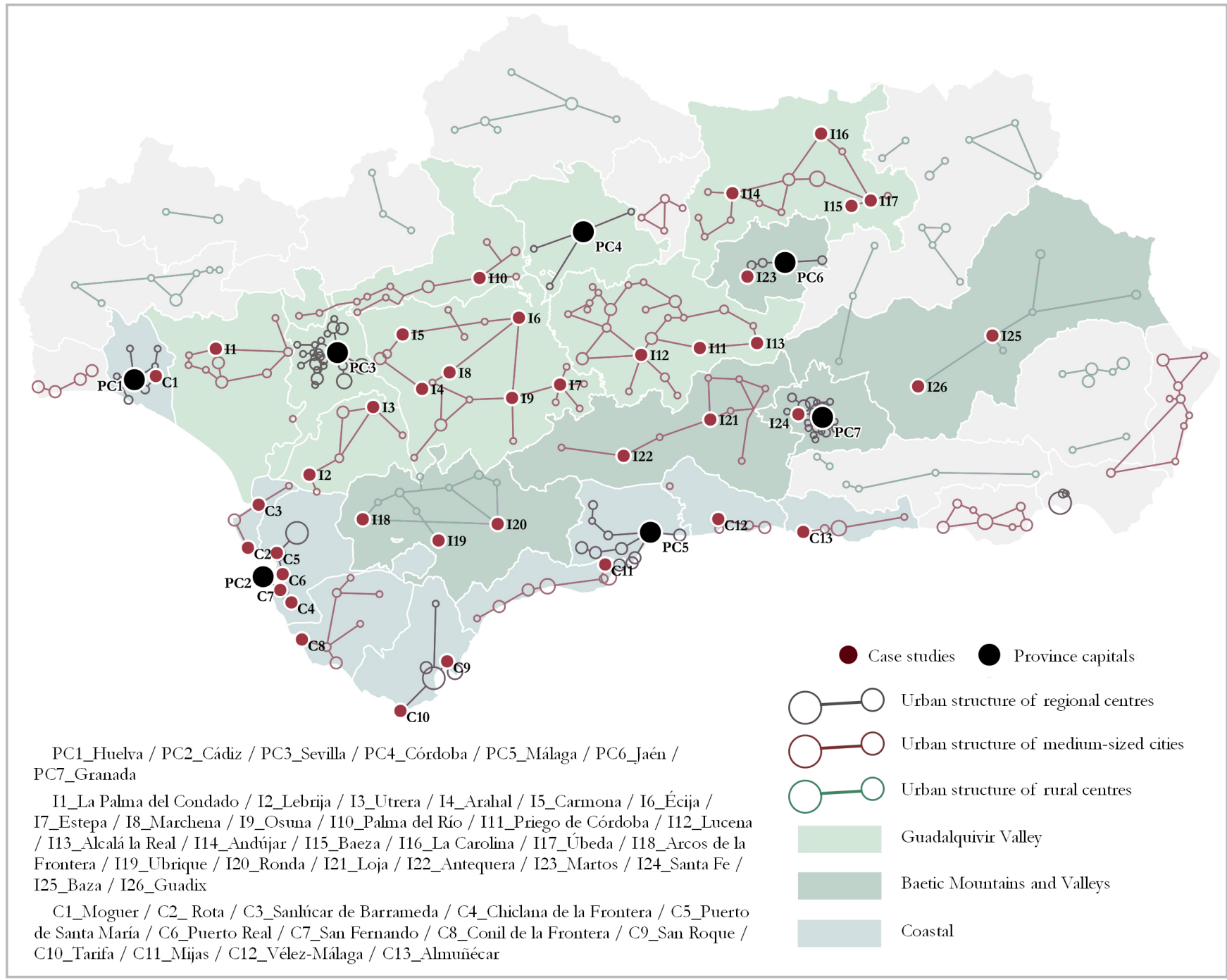

Figure 1.- Andalusian Urban System. Source: Compiled by the authors based on the Spatial Plan of Andalusia (Junta de Andalucía, 2006)

Table 1.- Geographic Domain, Territorial Unit and Medium-sized Cities listed as Historical Ensemble in Andalusia. Source: Compiled by authors based on data from the Spatial Plan of Andalusia (Junta de Andalucía, 2006) and the Institute of Statistics and Cartography of Andalusia (IECA, 2019).

\begin{tabular}{|c|c|c|c|}
\hline \multicolumn{2}{|c|}{ Geographic Domain } & Territorial Unit & $\begin{array}{l}\text { Medium-sized cities according to the Spatial Plan of Anda- } \\
\text { lusia }\end{array}$ \\
\hline \multirow{6}{*}{ Inner } & \multirow{6}{*}{$\begin{array}{l}\text { Guadalquivir } \\
\text { Valley }\end{array}$} & Aljarafe-Condado-Marismas & La Palma del Condado (10,761 inhabitants) \\
\hline & & Bajo Guadalquivir & $\begin{array}{l}\text { Lebrija }(27,524 \text { inhabitants }) \\
\text { Utrera (50,728 inhabitants) }\end{array}$ \\
\hline & & Campiña y Sierra Sur de Sevilla & $\begin{array}{l}\text { Arahal (19,526 inhabitants) } \\
\text { Carmona (28,531 inhabitants) } \\
\text { Écija ( } 39,873 \text { inhabitants) } \\
\text { Estepa (12,505 inhabitants) } \\
\text { Marchena ( } 19,457 \text { inhabitants }) \\
\text { Osuna (17,560 inhabitants) }\end{array}$ \\
\hline & & Guadalquivir Valley & Palma del Río (21,064 inhabitants) \\
\hline & & $\begin{array}{l}\text { Campiña y Subbético de Córdoba } \\
\text { y Jaén }\end{array}$ & $\begin{array}{l}\text { Lucena ( } 42,605 \text { inihabitants) } \\
\text { Priego de Córdoba ( } 22,408 \text { inhabitants) } \\
\text { Alcalá la Real ( } 21,605 \text { inhabitants) }\end{array}$ \\
\hline & & Centro Norte de Jaén & $\begin{array}{l}\text { Andújar ( } 36,793 \text { inhabitants }) \\
\text { Baeza (15,841 inhabitants) } \\
\text { La Carolina (15,261 inhabitants) } \\
\text { Úbeda ( } 34,345 \text { inhabitants) }\end{array}$ \\
\hline
\end{tabular}


Table 1.- (continuation)

\begin{tabular}{|c|c|c|c|}
\hline \multicolumn{2}{|c|}{ Geographic Domain } & \multirow{2}{*}{\begin{tabular}{|l} 
Territorial Unit \\
Serranías de Cádiz y Ronda
\end{tabular}} & \multirow{2}{*}{$\begin{array}{l}\text { Medium-sized cities according to the Spatial Plan of } \\
\text { Andalusia } \\
\text { Arcos de la Frontera ( } 30,700 \text { inhabitants) } \\
\text { Ubrique ( } 16,597 \text { inhabitants) } \\
\text { Ronda (33,877 inhabitants) }\end{array}$} \\
\hline \multirow{5}{*}{ Inner } & \multirow{5}{*}{$\begin{array}{l}\text { Baetic Mou- } \\
\text { ntains and } \\
\text { Valleys }\end{array}$} & & \\
\hline & & $\begin{array}{l}\text { Depresiones de Antequera y } \\
\text { Granada }\end{array}$ & $\begin{array}{l}\text { Loja }(20,342 \text { inhabitants }) \\
\text { Antequera ( } 41,239 \text { inhabitants) }\end{array}$ \\
\hline & & Regional Centre of Jaén & Martos (24,215 inhabitants) \\
\hline & & Regional Centre of Granada & Santa Fe $(15,157$ inhabitants $)$ \\
\hline & & Altiplanicies Orientales & $\begin{array}{l}\text { Baza }(20,412 \text { inhabitants }) \\
\text { Guadix }(18,422 \text { inhabitants })\end{array}$ \\
\hline \multirow{8}{*}{ Coastal } & & Regional Centre of Huelva & Moguer (22,088 inhabitants) \\
\hline & & Costa Noroeste de Cádiz & $\begin{array}{l}\text { Rota }(29,109 \text { inhabitants) } \\
\text { Sanlúcar de Barrameda ( } 68,684 \text { inhabitants) }\end{array}$ \\
\hline & & $\begin{array}{l}\text { Regional Centre of } \\
\text { Bahía de Cádiz-Jérez }\end{array}$ & $\begin{array}{l}\text { Chiclana de la Frontera ( } 84,489 \text { inhabitants) } \\
\text { Puerto de Santa María ( } 88,405 \text { inhabitants) } \\
\text { Puerto Real (41,627 inhabitants) } \\
\text { San Fernando }(95,979 \text { inhabitants) }\end{array}$ \\
\hline & & La Janda & Conil de la Frontera (22,529 inhabitants) \\
\hline & & $\begin{array}{l}\text { Regional Centre of } \\
\text { Bahía de Algeciras }\end{array}$ & $\begin{array}{l}\text { San Roque (31,218 inhabitants) } \\
\text { Tarifa (18,162 inhabitants) }\end{array}$ \\
\hline & & Costa del Sol & Mijas $(82,742$ inhabitants) \\
\hline & & Vélez-Málaga y Axarquía & Vélez-Málaga (81,643 inhabitants) \\
\hline & & Costa Tropical & Almuñécar (26,514 inhabitants) \\
\hline
\end{tabular}

\section{Methodology}

\section{- Criteria for its application to the study sample}

To meet the defined objectives, a system of mediumsized cities of heritage character has been chosen as a case study: those officially recognised in Andalusia purposing their preservation. That is, listed as Historical Ensembles according to what is indicated by Law 14/2007 on the Historical Heritage of Andalusia (Junta de Andalucía 2007). For this purpose, it has been necessary to determinate the criteria based on what urban vulnerability needs to be addressed.

In the case of the Spanish official framework, the Ministry of Development has developed a methodology to try to objectively analyse Urban Vulnerability through twenty urban indicators and from four perspectives (socio-demographic, socio-economic, residential and subjective). The resulting product can be checked on a web application, namely Atlas of Urban Vulnerability, firstly published in 2011. The methodology was reviewed to become part of the Urban Vulnerability Observatory in 2015, thanks to the approval of the Land and Urban Rehabilitation Law (Ministerio de Fomento 2015). This digital tool is playing a key role in the development of urban regeneration policies, including the Integrated Sustainable Urban Development Strategies (SUDS) as the result of implementing the Europe 2020 strategy to the field of urban development (Matesanz Parellada, 2018: 92).

This work adopts the methodology provided by the aforementioned Atlas using the data supplied by the Spanish National Statistics Institute in the most recent Population and Housing Census (2011). Although it is a statistical study based on $9 \%$ of regular residents, it is the last unified analysis for the set of Spanish municipalities and, therefore, with the same criteria for sampling, data collection and result interpretation. The next update is scheduled for release in 2021. Meanwhile, the National Statistics Institute elaborates the Continuous Household Survey annually since 2013. However, its data are grouped by provinces, and, consequently, it is not possible to use them in this research. Besides, the latest version of the Spanish Census does not provide the information needed for Subjective indicators; whose 
analysis would require a qualitative approach based on social perception (Ruiz, 2019:34). For this reason, the research has focused on the socio-demographic, socioeconomic and residential dimensions. Specifically, the following fifteen indicators have been analysed:

- Socio-demographic vulnerability: Percentage of seniors aged 75 or more (I1), Percentage of families with only a person aged 64 or more (I2), Percentage of families with only an adult and a child (I3), Percentage of foreign population (14), Percentage of foreign children (I5).

-Socio-economic vulnerability: Percentage of unemployed population (16), Percentage of unemployed young population (I7), Percentage of contingent workers (I8), Percentage of workers without qualification (19), Percentage of people without primary education (I10).

- Residential vulnerability: Percentage of dwellings with less than $30 \mathrm{~m}^{2}$ (I11), Average adequate living area by inhabitant (112), Percentage of population in dwellings without a toilet or WC (I13), Percentage of dwellings in ruined or deficient buildings (114), Percentage of dwellings in buildings built before 1940 (I15).

Based on these considerations, the fifteen indicators mentioned above have been applied to the twentysix medium-sized interior cities and thirteen coastal ones that have been listed as Heritage Ensembles. The numerical and percentage indicator values have been provided for the whole sample using the data supplied by the Population and Housing Census. This study includes a comparative analysis with the eight provincial capitals, which have the role of regional centres within the territorial organization of Andalusia. In order to properly analyse the results, two different general territorial domains should be identified within the set of Andalusian medium-sized cities. The geographical position, the substantial economic and demographic development or the particular dynamics of urban growth makes the coastal territorial structure differs significantly from the inner one, mostly traditionally characterised as agrocities. Besides, the territorial structure of inner Andalusia is marked by the presence of two structuring elements of the Andalusian territory: the Guadalquivir River and the Baetic System.

In the first phase, the complete information has been represented using a sequential colour scheme (the lowest levels in green and the highest ones in red), as shown in Tables 2 and 3. Subsequently, transforming the absolute values into quintiles, the general urban vulnerability index has been calculated, as well as the one corresponding to each of the three dimensions analysed: Socio-demographic, Socio-economic and Residential. The territorial distribution of these values has been represented through Geographic Information Systems, which has allowed to provide a territorial lecture of the urban vulnerability in Andalusia [figure 2].

\section{Results}

- Urban heritage protection. Urban planning as a preservation tool

Before evaluating the degree of heritage preservation that characterizes the analysed cities, it is necessary to expose the legal framework that currently regulates it. In Spain, the heritage preservation is carried out by different public administrations in various development levels: Central, Regional and Local Governments. The Government of Spain, through the Heritage Law, in force since 1985, can list heritage elements as Bien de Interés Cultural -hereafter BIC- (Cultural Interest Asset), the highest level of protection in the country. These elements can be listed as Monuments, Historical Gardens, Historical Ensembles, Historical Sites or Archaeological Areas.

Furthermore, heritage preservation can also be articulated since the regional level. Thus, in the case of Andalusia and after the transfer of competences in heritage matters in 1984, the first Andalusian Heritage Law was approved in 1991 (Junta de Andalucía 1991), updated in 2007 (Junta de Andalucía 2007). According to this law, the Cultural Interest Assets also be listed as Places of Ethnological Interest, Places of Industrial Interest, or Heritage Areas. Besides, it introduces a second level of heritage protection called Bien de Catalogación General -hereafter BCG- (General Cataloguing Asset). Both of them, and those Andalusian movable assets listed in the Inventario General de Bienes Muebles del Patrimonio Histórico Español (General Inventory of Movable Property of the Spanish Historical Heritage), are included in the Catálogo General del Patrimonio Histórico Andaluz -hereafter CGPHA- (General Catalogue of the Andalusian Historical Heritage).

Nonetheless, Local Governments has also a significant role in the safeguarding of heritage due to their proximity to the asset to be preserved. According to the Ley de Ordenación Urbanística de Andalucía -hereafter LOUA- (Andalusian Urban Planning Law), each municipality is obliged to include heritage preservation measures in the different urban planning instruments approved. In this sense, it is relevant to clarify that the Spanish legislation considers several urban development levels, whose impact on heritage preservation -given the scope of the measures- is consequently uneven. The first instrument to be considered is the Plan General de Ordenación Urbana -hereafter PGOU(General Urban Development Plan). In some cases, general urban planning is regulated by the so-called Normas Subsidiarias -hereafter NNSS- (Urban Subsidiary Rules). They are repealed instruments, but which are still used in small towns after being updated according to the LOUA's requirements.

On a second level, the Planes Especial de Protección hereafter PEP- (Preservation Urban Plans) should be mentioned. According to Article 14 of the LOUA, these plans have, among other purposes, to conserve, protect 
and improve the urban environment and, primarily, the bearer or expressive heritage of urban, architectural, historical or cultural values. In both instruments, the heritage preservation is mainly articulated through the socalled Protection Catalogues, which contain the detailed list and the precise identification of the assets and spaces that, due to their value, must be subject to particular conservation. Its formulation and approval can also be carried out independently.

According to the aforementioned urban and heritage preservation policies, the set of case studies have been analysed distinguishing again between interior and coastal geographic domain. As table 2 shows, 9 out of 26 (34.62\%) cities studied in inner Andalusia are still regulated with NNSS, 5 of them have initiated the drafting of their PGOU, but they have not been approved definitely. 15 out of 26 (57.69\%) of the General Plans had been approved before the LOUA's enactment, but all of them have been adapted to its articulate. Consequently, all the PGOU and NNSS include heritage preservation measures, although only 21 of them include a protection catalogue. In parallel, 10 out of $26(38.46 \%)$ cities have approved a Preservation Plan for their Historical Ensembles.

In the cities analysed in the coast, as table 3 shows, only 1 out of $13(7.69 \%)$ is still regulated by NNSS which were adapted to the current legal framework in 2010. 8 out of 13 (61.54\%) General Plans had been approved before the LOUA's enactment, but all of them have been already updated. Consequently, all the PGOU and NNSS include heritage preservation measures, although only 11 of them include a protection catalogue. One of them, the Puerto de Santa María, has approved an additional heritage register. About Preservation Planning for their Historical Ensembles, 10 out of $13(76.92 \%)$ cities have initiated its formulation; nevertheless, only 6 of them (46.15\%) have definitely approved it.

Table 2.- Heritage protection by urban planning in medium-sized interior cities. Source: Compiled by authors based on the Regional Government's Planning Database (Junta de Andalucía, 2019).

\begin{tabular}{|c|c|c|c|c|c|}
\hline MEDIUM-SIZED INTERIOR CITY & $\begin{array}{l}\text { CURRENT } \\
\text { URBAN PLAN }\end{array}$ & $\begin{array}{l}\text { PROTECTION } \\
\text { CATALOGUE }\end{array}$ & $\begin{array}{l}\text { ADAPTATION } \\
\text { TO LOUA }\end{array}$ & $\begin{array}{l}\text { PROTECTION } \\
\text { URBAN PLAN }\end{array}$ & $\begin{array}{l}\text { ADDITIONAL } \\
\text { REGISTER }\end{array}$ \\
\hline Arcos de la Frontera (Cádiz) & $\begin{array}{c}\text { PGOU } 1994 \\
\text { PGOU 2014(1) }\end{array}$ & Yes & 2010 & 2007 & - \\
\hline Ubrique (Cádiz) & $\begin{array}{l}\text { NNSS } 1987 \\
\text { PGOU } 2015^{(1)}\end{array}$ & Yes & 2010 & No & - \\
\hline Lucena (Córdoba) & PGOU 1999 & Yes & 2008 & No & - \\
\hline Palma del Río (Córdoba) & PGOU 2005 & Yes & - & No & - \\
\hline Priego de Córdoba (Córdoba) & PGOU 2015 & Yes & - & No & - \\
\hline Baza (Granada) & PGOU 2010 & Yes & - & No & - \\
\hline Guadix (Granada) & PGOU 2002 & Yes & 2010 & No & - \\
\hline Loja (Granada) & NNSS 1993 & Yes & 2009 & No & - \\
\hline Santa Fe (Granada) & NNSS 1998 & $\mathrm{Yes}^{(2)}$ & 2009 & No & - \\
\hline La Palma del Condado (Huelva) & PGOU 2005 & Yes & - & No & - \\
\hline Alcalá la Real (Jaén) & PGOU 2005 & Yes & - & No & - \\
\hline Andújar (Jaén) & PGOU 2010 & Yes & - & No & - \\
\hline Baeza (Jaén) & PGOU 2011 & Yes & - & 1990 & - \\
\hline La Carolina (Jaén) & NNSS 1993 & Yes & 2011 & No & - \\
\hline Martos (Jaén) & PGOU 2013 & Yes & - & No & - \\
\hline Úbeda (Jaén) & PGOU 1996 & $Y_{e s}^{(2)}$ & 2009 & $1989^{(3)}$ & - \\
\hline Antequera (Málaga) & PGOU 2010 & $Y_{e s}^{(2)}$ & - & 1993 & - \\
\hline Ronda (Málaga) & PGOU 1991 & $\mathrm{Yes}^{(2)}$ & 2010 & - & - \\
\hline Arahal (Sevilla) & $\begin{array}{c}\text { NNSS } 1994 \\
\text { PGOU 2019(1) }\end{array}$ & Yes & 2009 & 2014 & - \\
\hline Carmona (Sevilla) & $\begin{array}{c}\text { NNSS } 1983 \\
\text { PGOU 2012 } \\
\end{array}$ & Yes & 2009 & 2009 & - \\
\hline Écija (Sevilla) & PGOU 2009 & Yes & - & 2002 & - \\
\hline Estepa (Sevilla) & NNSS 1988 & Yes & 2011 & - & - \\
\hline Lebrija (Sevilla) & PGOU 2016 & Yes & - & 2018 & - \\
\hline Marchena (Sevilla) & $\begin{array}{c}\text { NNSS } 1995 \\
\text { PGOU } 2007^{(1)}\end{array}$ & Yes & 2009 & 1994 & - \\
\hline Osuna (Sevilla) & $\begin{array}{c}\text { NNSS } 1985 \\
\text { PGOU } 2017^{(1)} \\
\end{array}$ & Yes $^{(2)}$ & 2009 & - & - \\
\hline Utrera (Sevilla) & $\begin{array}{l}\text { PGOU } 2001 \\
\text { PGOU } 2015^{(1)}\end{array}$ & Yes & 2008 & $2009^{(4)}$ & - \\
\hline
\end{tabular}


Table 3.- Heritage protection by urban planning in medium-sized interior cities. Source: Compiled by authors based on the Regional Government's Planning Database (Junta de Andalucía, 2019).

\begin{tabular}{|c|c|c|c|c|c|}
\hline $\begin{array}{l}\text { MEDIUM-SIZED } \\
\text { COASTAL CITY }\end{array}$ & $\begin{array}{l}\text { CURRENT } \\
\text { URBAN PLAN }\end{array}$ & $\begin{array}{l}\text { PROTECTION } \\
\text { CATALOGUE }\end{array}$ & $\begin{array}{l}\text { ADAPTATION } \\
\text { TO LOUA }\end{array}$ & $\begin{array}{l}\text { PROTECTION } \\
\text { URBAN PLAN }\end{array}$ & $\begin{array}{c}\text { ADDITIONAL } \\
\text { REGISTER }\end{array}$ \\
\hline Chiclana de la Frontera (Cádiz) & PGOU 2016 & Yes & - & - & - \\
\hline Conil de la Frontera (Cádiz) & PGOU 2005 & No & 2013 & $2003^{(1)}$ & - \\
\hline El Puerto de Santa María (Cádiz) & PGOU 2012 & Yes & & $2009^{(1)}$ & 2015 \\
\hline Puerto Real (Cádiz) & PGOU 2009 & Yes & - & 1997 & - \\
\hline Rota (Cádiz) & PGOU 1994 & Yes & 2009 & $2019^{(1)}$ & - \\
\hline San Fernando (Cádiz) & PGOU 2011 & Yes & - & 2008 & - \\
\hline San Roque (Cádiz) & PGOU 2000 & Yes & 2009 & 2009 & - \\
\hline Sanlúcar de Barrameda (Cádiz) & PGOU 1996 & Yes & 2011 & - & - \\
\hline Tarifa (Cádiz) & PGOU 1989 & Yes & 2010 & 2012 & - \\
\hline Almuñécar (Granada) & PGOU 1987 & Yes $^{(2)}$ & 2009 & 2013 & - \\
\hline Moguer (Huelva) & NNSS 1992 & Yes & 2010 & - & - \\
\hline Mijas (Málaga) & PGOU 1999 & Yes $^{(2)}$ & 2010 & $2019^{(1)}$ & - \\
\hline Vélez-Málaga (Málaga) & PGOU 1996 & No & 2009 & $2008^{(3)}$ & - \\
\hline
\end{tabular}

The medium-sized coastal cities present average levels of vulnerability in the three dimensions that have been analysed. All the indicators are comprised between the second and fourth quintile. It should be noted that their socio-demographic vulnerability is lower to the regional centres. This fact is especially significative in the percentage of the elderly population (I1-I2) and the percentage of single-parent families (I3). By the contrary, their socioeconomic vulnerability is slightly higher (I6-I10). Although they are characterised for certain uniformity, some general conclusions can be drawn. In average, they also present medium levels of vulnerability in the three dimensions. The results are similar to the coastal cities; being the indicators comprised between the second and fourth quintile. The socio-demographic vulnerability (I1-15) is lower to the regional centres and the socio-economic vulnerability slightly higher (16-I10). The residential vulnerability can be considered equivalent in both cases since half of the indicators are slightly higher in medium-sized cities and the other half in the regional centres [figure 2].

In inner Andalusia [table 3], two particular situations can be recognised based on the intensity and level of consolidation of these territories: Guadalquivir Valley (high intensity) and Baetic Mountains and Valleys (moderate intensity). In the first case, the territorial unities of the Campiña de Sevilla and the Bajo Guadalquivir should be highlighted. As table 3 shows, cities such as Arahal, Carmona, Écija, Lebrija, Marchena, Osuna or Utrera stand out for higher values in socio-economic vulnerability (I6-I10) compared to the rest of the dimensions except for Estepa. This city also has high levels of socio-economic vulnerability, but exclusivately in

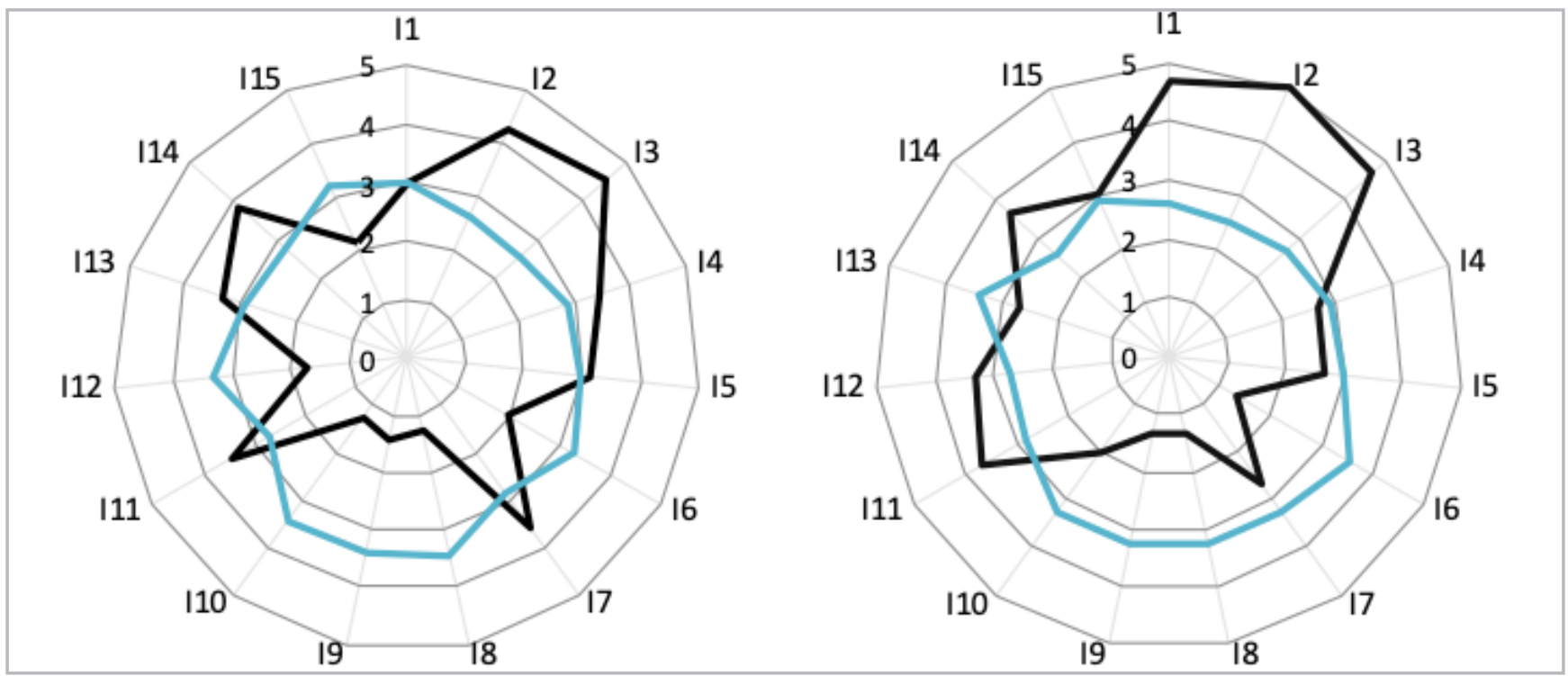

Figure 2.- Average levels of urban vulnerability in medium-sized cities (blue) and regional centres (black) in inner and coastal Andalusia. Source: Compiled by the authors based on data from Spanish Statistical Office (INE, 2011). 
indicators 17 to 18 . These data do not mean that the other values are in minimum positions. Thus, cities as Estepa, Lebrija, Marchena or Osuna show high levels of residential vulnerability, specially I15.

Besides, for the cases of Estepa and Lebrija, high levels are observed in indicators I12, I13 and I14. In the North-Centre of Jaén, the principal characteristic is the vulnerability levels of La Carolina. In this case, most of the indicators are at low levels. 9 out of 18 (50\%) are under the first percentile except for indicators 16 and 113 which levels are close to the maximum. Furthermore, Priego de Córdoba stands out among the group of cities that constitute the Campiña and Subbética de Córdoba-Jaén. This medium-sized city has almost non-existent levels of residential vulnerability, on the contrary, has maximum levels in 14, 15, 18, 19 and 110 indicators. La Palma del Condado and Palma del Río, the only example analysed in their related territorial unit, are characterized by having most of their values at minimum levels.

In the Baetic Mountains and Valleys, five territorial units have been analysed. Among the case studies, Baza highlights as the city that presents the highest number of indicators at maximum levels at the axis drawn by the cities inserted in the Altiplanicies Orientales and the Depresiones de Antequera y Granada. Mainly those related to residential issues, although some indicators of socio-economic and socio-demographic vulnerabilities also have maximum values. Antequera presents the lowest

Table 3.- Urban vulnerability in medium-sized cities (blue) and regional centres (black) in inner Andalusia (percentage figures). Data has been represented using a sequential colour scheme (the lowest levels in green and the highest ones in red). Observations: ${ }^{(1)}$ no foreign children registered; (2) no dwellings with less than $30 \mathrm{~m}^{2}$ registered; ${ }^{(3)}$ no dwellings without a toilet or WC registered. Source: Compiled by the authors based on data from Spanish Statistical Office (INE, 2011)

\begin{tabular}{|c|c|c|c|c|c|c|c|c|c|c|c|c|c|c|c|c|}
\hline Cities & I1 & I2 & I3 & I & & I5 & I6 & I7 & I8 & I9 & I10 & I11 & I12 & I13 & I14 & I15 \\
\hline Cádiz & 9,08 & 4,18 & 5,71 & 1,7 & & 0,11 & 19,03 & 59,71 & 34,40 & 20,12 & 9,74 & 0,73 & 31,51 & 1,38 & 15,08 & 22,78 \\
\hline Arcos de la Frontera & 6,34 & 2,34 & 3,81 & 2,2 & & 0,59 & 28,47 & 61,56 & 55,87 & 55,83 & 17,01 & 0,60 & 30,74 & 1,62 & 4,57 & 11,55 \\
\hline Ubrique & 7,62 & 3,05 & 4,44 & 0,8 & & 0,24 & 18,28 & 46,11 & 47,74 & 12,38 & 20,12 & 0,47 & 34,35 & 1,18 & 5,83 & 9,38 \\
\hline Córdoba & 8,32 & 3,61 & 5,71 & 2,6 & & 0,37 & 17,75 & 51,22 & 31,05 & 17,41 & 9,91 & 0,14 & 33,24 & 0,62 & 6,76 & 6,14 \\
\hline Lucena & 7,05 & 2,69 & 4,18 & 5,3 & & 0,61 & 21,36 & 47,10 & 38,57 & 27,55 & 14,63 & 0,17 & 34,68 & 2,26 & 4,62 & 2,46 \\
\hline Palma del Río & 7,69 & 3,24 & 4,01 & 5,5 & & 1,40 & 19,72 & 46,61 & 48,47 & 45,72 & 17,83 & $0,00(2)$ & 33,79 & 0,52 & 1,10 & 2,72 \\
\hline Priego de Córdoba & 10,97 & 3,74 & 6,02 & 2,6 & & 0,92 & 19,61 & 43,80 & 44,48 & 39,85 & 18,65 & $0,00(2)$ & 40,28 & 0,72 & 3,36 & 8,05 \\
\hline Granada & 9,72 & 4,79 & 6,67 & 7,0 & & 1,24 & 15,93 & 53,49 & 29,60 & 14,27 & 7,73 & 0,33 & 38,43 & 0,46 & 5,49 & 5,61 \\
\hline Baza & 9,31 & 3,62 & 4,37 & 9,5 & & 2,51 & 17,44 & 49,47 & 35,92 & 22,59 & 13,32 & $0,00^{(2)}$ & 43,78 & 0,52 & 5,50 & 7,25 \\
\hline Guadix & 9,86 & 3,64 & 3,61 & 3,6 & & 0,82 & 17,43 & 51,23 & 37,46 & 25,06 & 11,61 & 1,35 & 36,96 & 0,28 & 14,84 & 22,02 \\
\hline Loja & 8,87 & 4,46 & 4,01 & 5, & & 1,70 & 19,76 & 37,33 & 43,99 & 40,84 & 19,34 & 0,50 & 39,74 & 0,44 & 8,71 & 7,77 \\
\hline Santa Fe & 7,74 & 2,09 & $8,7 c$ & 4,3 & & $0,00^{(1)}$ & 18,59 & 53,33 & 38,14 & 23,36 & 9,65 & 1,50 & 38,27 & 0,44 & 1,86 & 6,02 \\
\hline Huelva & 7,26 & 3,18 & 5,95 & 4, s & & 0,82 & 18,87 & 56,12 & 36,76 & 23,73 & 8,11 & 0,09 & 31,70 & 0,62 & 11,81 & 4,52 \\
\hline La Palma & 7,77 & 2,55 & $4,3 c$ & 3, & & 0,57 & 16,87 & 39,63 & 40,86 & 31,47 & 8,32 & $0,00(2)$ & 37,15 & 0,28 & 4,55 & 12,69 \\
\hline Jaén & 8,00 & 3,98 & 6,50 & 2,5 & & 0,43 & 15,38 & 61,05 & 30,49 & 17,41 & 8,75 & $0,00^{(2)}$ & 35,16 & 0,53 & 3,66 & 4,15 \\
\hline Alcalá la Real & 11,98 & 5,08 & 3,41 & 4,8 & & 0,99 & 15,84 & 46,46 & 41,65 & 33,83 & 21,45 & 0,23 & 42,09 & 1,09 & 4,15 & 4,67 \\
\hline Andrijar & 8,76 & 3,70 & 4,81 & $2, c$ & & 0,44 & 21,29 & 58,99 & 38,54 & 29,98 & 17,42 & $0,00(2)$ & 35,67 & 0,31 & 8,32 & 4,12 \\
\hline Baeza & 9,15 & 4,26 & 3,98 & 4,4 & & 0,18 & 17,00 & 40,32 & 38,81 & 19,63 & 13,56 & $0,00(2)$ & 40,33 & $\left.0,00^{(}\right)$ & 1,05 & 7,37 \\
\hline La Carolina & 7,25 & 2,61 & 4,47 & 2, & & $0,00^{(1)}$ & 19,99 & 43,78 & 32,67 & 23,90 & 13,16 & $0,00^{(2)}$ & 36,25 & 0,18 & 0,98 & 6,39 \\
\hline Martos & 10,21 & 3,82 & 4,3 & 4,5 & & 1,37 & 17,32 & 42,16 & 39,16 & 33,72 & 16,99 & $\left.0,00()^{2}\right)$ & 38,97 & 0,50 & 5,91 & 13,15 \\
\hline Úbeda & 8,79 & 3,26 & 5,31 & 2, & & 0,36 & 18,16 & 49,61 & 33,09 & 15,25 & 11,03 & 0,12 & 39,68 & 0,19 & 3,86 & 10,49 \\
\hline Málaga & 7,21 & 3,52 & 6,18 & $7, \varepsilon$ & & 1,39 & 18,73 & 51,99 & 31,83 & 21,33 & 9,40 & 0,30 & 33,15 & 0,70 & 4,42 & 3,90 \\
\hline Antequera & 8,17 & 3,37 & 4,98 & 4,5 & & 0,93 & 3,65 & 52,82 & 33,05 & 28,07 & 14,76 & $0,00^{(2)}$ & 34,65 & 1,65 & 6,42 & 5,41 \\
\hline Ronda & 8,48 & 3,50 & $5,7 c$ & 4,1 & & 0,63 & 20,93 & 51,95 & 37,32 & 21,32 & 12,82 & 0,44 & 35,56 & 0,88 & 3,53 & 8,02 \\
\hline Sevilla & 8,28 & 3,95 & 5,51 & 5,1 & & 0,94 & 16,54 & 50,20 & 29,21 & 16,79 & 7,85 & 0,22 & 32,97 & 0,54 & 4,81 & 4,55 \\
\hline Arahal & 7,28 & 1,77 & 2,64 & 1,3 & & 0,21 & 24,32 & 60,04 & 49,05 & 52,23 & 16,93 & 0,18 & 34,29 & $0,00^{(3)}$ & 5,00 & 4,33 \\
\hline Carmona & 7,54 & 2,22 & 4,7 & 2 & & 0,83 & 24,31 & 57,00 & 44,61 & 47,50 & 14,57 & $0,00(2)$ & 36,33 & 1,18 & 1,69 & 7,30 \\
\hline Écija & 7,14 & 3,14 & 7,0 & 2 & & 1,05 & 23,32 & 57,25 & 44,97 & 35,63 & 15,41 & 0,03 & 33,93 & 1,12 & 2,86 & 4,58 \\
\hline Estepa & 7,30 & 0,35 & 3,9 & 3 , & & $0,00^{(1)}$ & 15,06 & 57,88 & 47,30 & 27,25 & 14,62 & 0,17 & 42,35 & 1,50 & 1,50 & 11,95 \\
\hline Lebrija & 6,20 & 2,42 & 4,2 & 2 & & 0,20 & 23,05 & 55,36 & 44,15 & 30,52 & 15,99 & 0,17 & 33,71 & 1,01 & 4,27 & 7,12 \\
\hline Marchena & 7,67 & 2,98 & 5,0 & 3, & & 0,10 & 21,26 & 59,19 & 46,50 & 42,83 & 17,55 & $0,00(2)$ & 36,14 & 0,00 (ङ) & 2,27 & 7,37 \\
\hline Osuna & 8,48 & 2,34 & 3,7 & 1 ; & & 0,17 & 20,10 & 57,28 & 47,38 & 51,91 & 16,26 & 0,12 & 38,77 & 0,00 (3) & 6,34 & 11,58 \\
\hline Utrera & 6,24 & 2,22 & 4,9 & 2 & & 0,50 & 25,15 & 62,16 & 41,23 & 32,47 & 13,84 & 0,35 & 35,56 & 0,38 & 2,61 & 5,07 \\
\hline Regional centres & 8,26 & 3,93 & 6,0 & 4, & & 0,82 & 17,42 & 55,43 & 32,05 & 18,94 & 8,60 & 0,28 & 33,82 & 0,71 & 7,54 & 7,59 \\
\hline Medinm-sized cities & 8,23 & 3,02 & 4,6 & 3 , & & 0,67 & 19,55 & 51,09 & 41,96 & 32,72 & 15,26 & 0,25 & 37,08 & 0,70 & 4,45 & 8,03 \\
\hline
\end{tabular}


levels of this region. However, it has two maximums in indicators concerning building matters (I13 and 114). Among the medium-sized cities of the Serranía de Cádiz and Ronda, Arcos de la Frontera has the highest values, mainly in the socio-economic dimension. In this sense, the similarity that exists between this city and Conil de la Frontera and Sanlúcar de Barrameda should be pointed out. These two coastal cities of the province of Cádiz also have maximum values in these indicators. Nevertheless, Ubrique is characterised by a higher level of vulnerability in residential areas. Finally, Santa Fe and Martos are located under the influence of a regional centre (Granada and Jaen, respectively). This fact makes them have similar patterns of behaviour as them. Just in the case of Martos, the indicators concerning population age (I1) and building age (I14-I15) are exceptionally higher than in Jaen.

On the other side, in the territorial domain of the Andalusian coast [table 4], the regional plan recognises eight territorial units mainly constituted by medium-sized cities. Two of these units are characterised by economic and productive factors: Costa del Sol and Poniente Almeriense (Navas-Carrillo et al., 2017:300). They appear as strongly anthropized units that have a monofunctional model (tourism or greenhouse agriculture). Within these two territorial units, the study sample only includes the city of Mijas. Highly polarised levels of vulnerability characterise this city. The vulnerability level in most of the indicators is minimum, even non-existent. However, the socio-demographic indicators (12-15) and the ones related to the housing surface (I11-I12) reach maximum values.
Meanwhile, the rest of the cases are less populated territorial units. Their functional model relates the two previous economic pillars - tourism and agriculture - with other development factors of urban, industrial and commercial economies. We highlight the case of Sanlúcar de Barrameda (Northwest Coast of Cadiz), Conil de la Frontera (La Janda), Vélez-Málaga (Axarquía) and Almuñecar (Costa Tropical), since they are the primary functional centres of their respective territories. The first two cities present high vulnerability in indicators 6 to 10 , relating to economic aspects. This weakness is seen as a risk factor for heritage preservation. The situation in Vélez-Málaga and Almuñecar is not favourable either. Both stands out for high levels of vulnerability, except for indicators linked to the employment (18) and the state of dwellings (114) in Vélez-Malaga, and the young unemployment (I7) and the number of single-parent families (I3) in the case of Almuñecar. In any case, analysed as a whole, high vulnerability implies a generalized risk in both cases.

Other coastal cities as Chiclana de la Frontera, Puerto Real, San Fernando, San Roque, Tarifa, Puerto de Santa María or Moguer have also been included in the sample. It should be explained that they can be classified as medium-sized cities considering population criteria exclusively. However, these cities are under the strong influence of a nearby regional centre. This fact encourages their response to urban vulnerability differs from the previous ones. The case of San Fernando should be highlighted. As table 4 shows, it has the same pattern of behaviour as Cádiz, but having vulnerability indexes lightly inferior.

Table 4.- Urban vulnerability in medium-sized cities (blue) and regional centres (black) in coastal Andalusia (percentage figures). Data has been represented using a sequential colour scheme (the lowest levels in green and the highest ones in red). Observations: ${ }^{(1)}$ no dwellings with less than $30 \mathrm{~m}^{2}$ registered. Source: Compiled by the authors based on data from Spanish Statistical Office (INE, 2011)

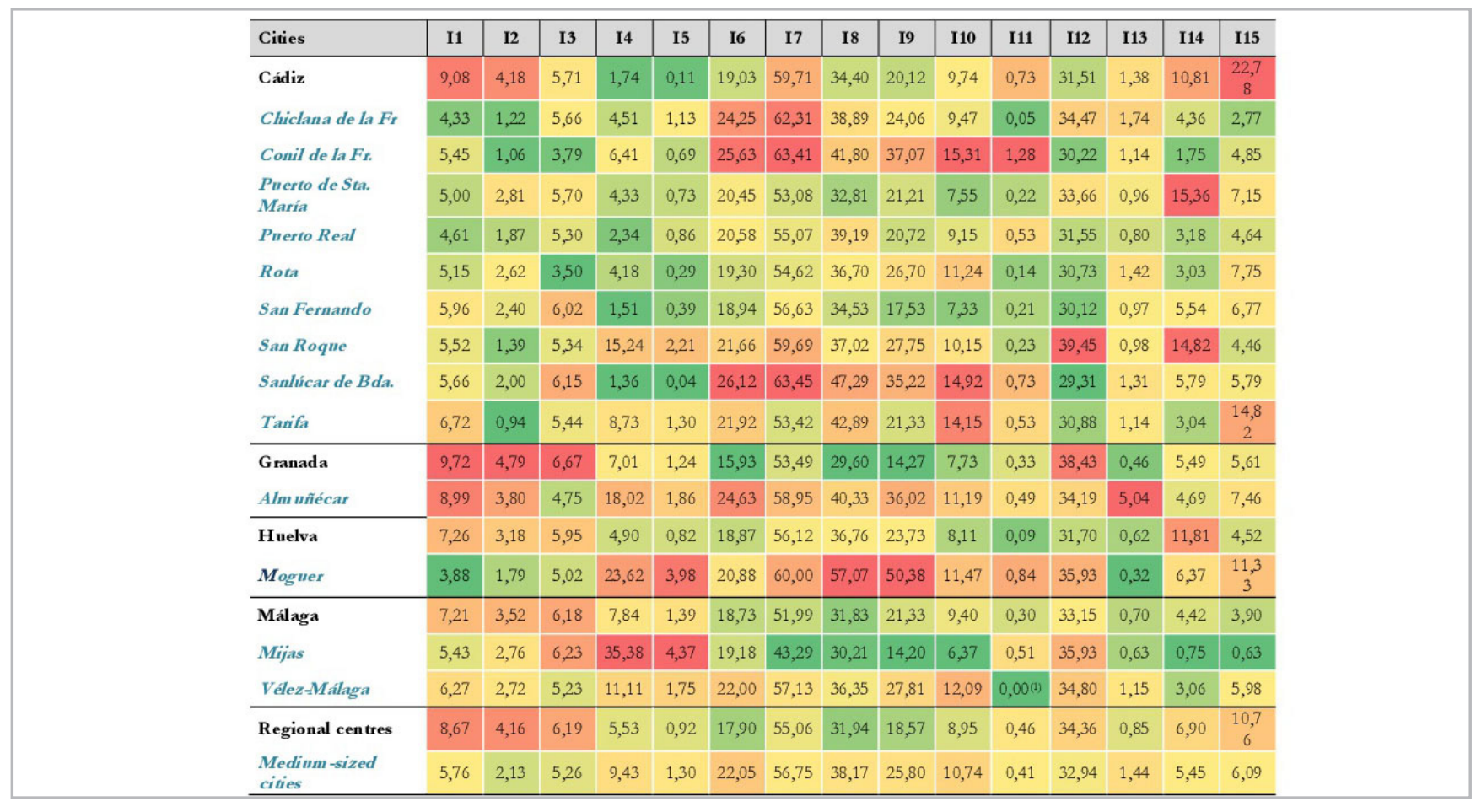




\section{Discussions and conclusions}

After analysing the results obtained, clear divergences can be observed between the vulnerability indexes that characterise each city of the sample. However, there is evidence of common trends or behaviour patterns in the set of cities under research, many of them since a territorial lecture. Most of the medium-sized cities highlight for their vulnerability in indicators 16 to 110 associated with socioeconomic aspects, in contrast to regional centres or those intermediate cities close to them. The level of indicators 17, related to youth unemployment, is especially significant in the provinces of Cádiz and Jaén, and lower in the provinces of Granada and Jaén. In fact, as figure 3 shows, the territorial units of western Andalusia present a higher average level of socio-economic vulnerability. Mainly, the medium-sized cities studied in the Campiña y Sierra Sur de Sevilla, in the Bajo Guadalquivir, Costa Noroeste de Cádiz, and the regional centre of Bahía de Cádiz. By contrast, the case studies in the provinces of Granada, Málaga, Córdoba and Jaén have higher average levels of socio-demographic vulnerability (11-15). The regional centres also show high vulnerability indexes, highlighting the case of Granada.

In the case of residential vulnerability (111-I15), there is a more uniform territorial distribution of values [figure 3]. However, slightly lower values are identified in many of the cities that have been analysed in the Guadalquivir valley. This fact reflects that settlements with a more significant relationship with the natural environment contribute to social equity to a greater extent than in province capitals, being something that affects the state of the houses. In this sense, the data obtained are considered positive since they involve greater social cohesion and a sense of belonging to a site. There intangible factors are of vital interest to the effective heritage safeguard. However, figure 3 also shows that in the vast majority of case studies, the values obtained in the three dimensions are compensated. As a result, the average vulnerability reaches medium levels, both in intermediate cities and regional centres.

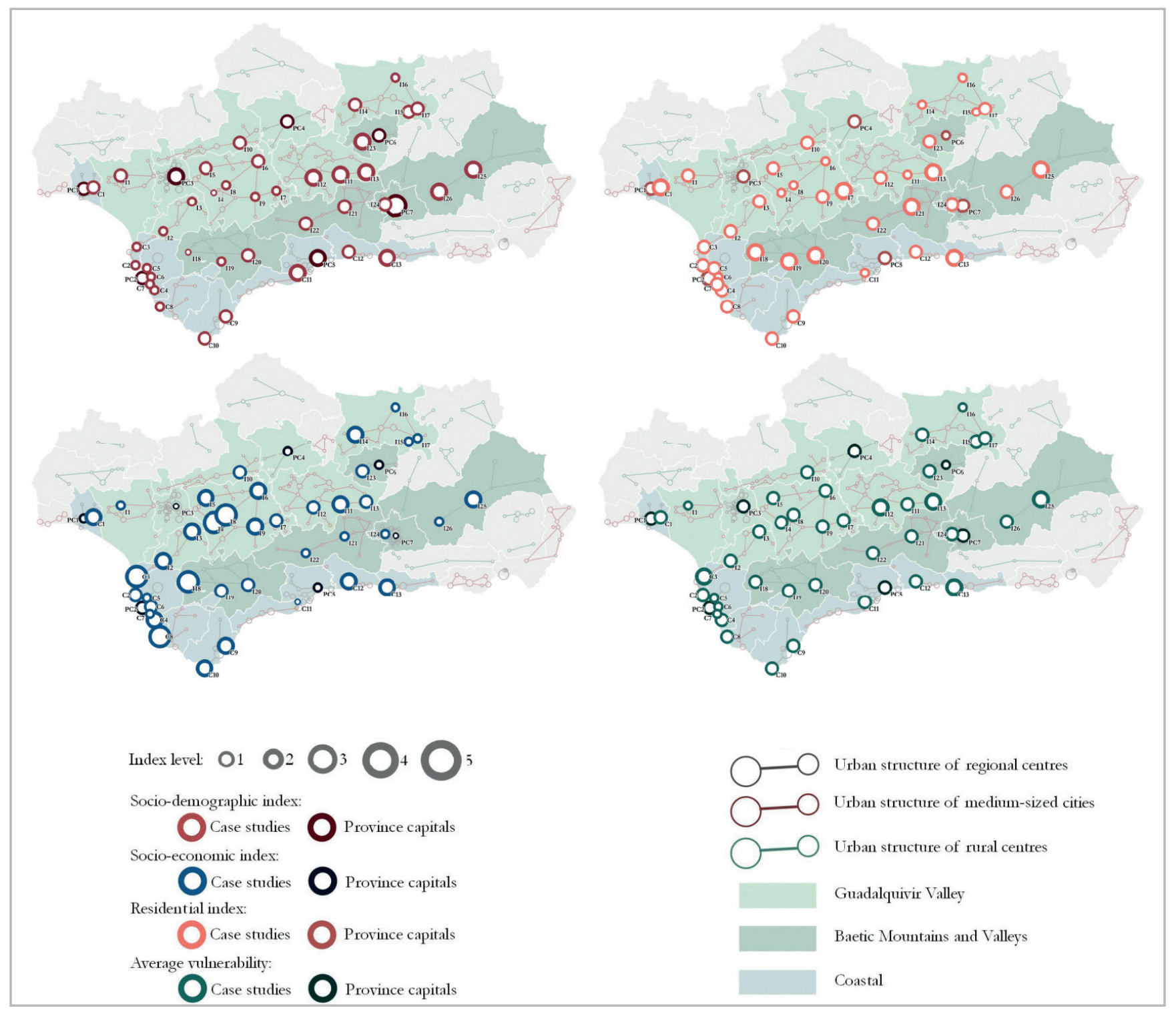

Figure 3.- Socio-demographic (red), socio-economic (blue), residential (green) and average (green) vulnerability in medium-sized cities (light colour) and regional centres (dark colour) in Andalusia. Source: Compiled by the authors based on data from Spanish Statistical Office (INE, 2011) 
The data also allow extracting significant differences between the cities analysed in inland and coastal Andalusia. The majority of medium-sized interior cities have high levels of uneducated population, probably due to their configuration in the past as agricultural cities. This lower level of education could lead to a lower knowledge in heritage matters, so it would be desirable to promote the training and information of society to bring it to know, value and respect its historical legacy.

Coastal cities stand out for having the highest levels of economic vulnerability (I6-110) and levels of foreigners (14). The economic weakness can be perceived as a risk factor for heritage preservation; however, the influence of the foreign population would require more in-depth analysis. Among other issues, it will depend on the greater or lesser contribution of them to the socio-economic level of the city, for example, if the number of foreigners is compared between the Costa del Sol and the Costa Tropical in Granada. Consequently, the positive and negative effects of tourism must also be considered. The development of coastal cities has been characterised by sun-andbeach tourism. However, cultural tourism has recently been promoted as an alternative, beginning to play an essential role in preserving the heritage and promoting urban regeneration also in coastal cities. Nevertheless, cultural tourism can also carry certain risks for heritage conservation when it becomes the predominant activity in high-value areas such as the Historical Ensembles hindering their normal performance.

To conclude, the results obtained generally show that the medium-sized cities of Andalusia do not present a level of vulnerability lower to the regional centres. Consequently, both would have a similar heritage management capacity. However, several urban weaknesses have been identified, which would demand complementary analysis, for instance, expanding the study to the whole Andalusian territory or updating it with future census data. Likewise, it could also imply a comparative analysis with other national and international contexts Future lines of research that would contribute to a better understanding of urban vulnerability and improve the efficiency of the tools currently used for cultural heritage preservation.

\section{Acknowledgements}

This paper has been developed under the R\&D project entitled Urban Heritage Characterisation and Cultural Tourism Model in Medium-Sized Cities. Potentialities and Challenges for its Internationalisation: Inner Baetica, funded by the competitive call of the State Plan 2013- 2016 Excellence - R\&D Projects of the Ministry of Economy and Competitiveness of the Government of Spain (HAR2016-79788-P).

\section{References}

ALGUACIL GÓMEZ, J. (2006): "Barrios desfavorecidos: un diagnóstico de la situación española". En: V Informe FUHEM de políticas sociales: La exclusión social y Estado de Bienestar en España: 155-168. Madrid: FUHEM-Icaria.

ALGUACIL GÓMEZ, J.; CAMACHO GUTIÉRREZ, J., HERNÁNDEZ AJA, A. (2014). "La vulnerabilidad urbana en España. Identificación y evolución de los barrios vulnerables". EMPIRIA. Revista de Metodología de Ciencias Sociales, 27: 73-94. https:// doi.org/10.5944/empiria.27.2014.10863

ANTÓN-ALONSO, F., PORCEL, S. (2017). "Transformación de barrios y densidad institucional: un análisis de la vulnerabilidad urbana en el Área Metropolitana de Barcelona". Seminario Internacional Las grandes ciudades en transformación. Dinámicas residenciales, segregación y vulnerabilidad. Barcelona: Universitat de Barcelona.

BANKOFF G., FRERK G., HILHORST, D. (2004). Mapping Vulnerability: Disasters, Development \& People. London: Earthscan

BANKOFF, G. (2019) Remaking the world in our own image: vulnerability, resilience and adaptation as historical discourses. Disasters. 43 (2): 221- 239. https://doi.org/10.1111/disa.12312

BELLET SANFELIU, C., BELTRÃO SPOSITO, M. E. (2009). Las ciudades medias o intermedias en un mundo globalizado. Lleida: Universitat de Lleida.

BELLET SANFELIU, C.; LLOP TORNÉ, J. M. (1999). Ciudades Intermedias y Urbanización Mundial. Lleida: UNESCO, Ayuntament de Lleida, UIA, Ministerio de Asuntos Exteriores.

BRAUN, G., HOGENBERG, F. (1572-1618). Civitates Orbis Terrarum. Colonia.

CANNON, T. (2008). Reducing People's Vulnerability to Natural Hazards: Communities and Resilience. Bonn: United Nations University - World Institute for Development Economics Research

CARDOSO, M. M. (2018). "Estudio de la vulnerabilidad y la resiliencia en la ciudad de Santa Fe, Argentina: El rol de los servicios urbanos en general y del transporte de pasajeros en particular". Revista de geografía Norte Grande, 73: 133-159. https://doi.org/10.4067/S0718-34022019000200133

CHRISTALLER, W. (1993). Die zentralen Orte in Süddeutschland (Central Places in Southern Germany). Translated by J. Fischer. New Jersey: Prentice-Hall.

DE SANTIAGO RODRÍGUEZ, E. (2018). "Herramientas de diagnóstico para las intervenciones de regeneración urbana integrada en la ciudad consolidada: ejemplos de España". Limaq. Revista de Arquitectura de la Universidad de Lima, 4: 219246. https://doi.org/10.26439/limaq2018.n004.2658 
DEL ESPINO HIDALGO, B. (2018). Las ciudades medias del centro de Andalucía. Análisis territorial y evaluación de su sostenibilidad. Sevilla: Editorial de la Universidad de Sevilla.

DEL ESPINO HIDALGO, B., NAVAS-CARRILLO, D. (2018). "Planeamiento estratégico local y evaluación del Desarrollo Urbano Sostenible Integrado en ciudades medias". Gestión y Análisis de Políticas Públicas, 20: 143-163. https://doi. org/10.24965/gapp.v0i20.10481

HERNÁNDEZ AJA, A., RODRÍGUEZ ALONSO, R., RODRÍGUEZ SUÁREZ, I. (Dir.) (2018). Barrios vulnerables de las grandes ciudades españolas. 1991/2001/2011. Madrid: Instituto Juan de Herrera (IJH).

EUROPEAN UNION (2001). Cities of tomorrow: Challenges, visions, ways forward. Online: http://ec.europa.eu/regional policy/sources/docgener/studies/pdf/citiesoftomorrow/ citiesoftomorrow final.pdf (accessed 19th October 2019)

FAULKNER, J.; MURPHY, E. \& SCOTT, M. (2020). Developing a holistic 'vulnerability-resilience' model for local and regional development. European Planning Studies. First published Online. https://doi.org/10.1080/09654313.2020.1720612

FÜSSEL, H. M. (2007). "Vulnerability: A generally applicable conceptual framework for climate change research". Global Environmental Change 17: 155-167. https://doi.org/10.1016/j. gloenvcha.2006.05.002

GODSCHALK, D. R. (2003). “Urban hazard mitigation: creating resilient cities". Natural hazards review, 4(3): 136-143. https:// doi.org/10.1061/(ASCE)1527-6988(2003)4:3(136)

HARVEY, D. (2003). "The right to the city". International journal of urban and regional research, 27(4): 939-941. https://doi. org/10.1111/j.0309-1317.2003.00492.x

HAWKES, J. (2001). The fourth pillar of sustainability. Culture's Essential Role in Public Planning. Melbourne, Australia.

HIRSCHMAN, A. O. (1958). The strategy of economic development. New Haven: Yale University Press.

JEFATURA DEL ESTADO. (1985). "Ley 16/1985, de 25 de junio, del Patrimonio Histórico Español". In: BOE núm. 155, de 29 de junio de 1985. Reference: BOE-A-1985-12534. Madrid.

JUNTA DE ANDALUCÍA (2002). "Ley 7/2002, de 17 de diciembre, de Ordenación Urbanística de Andalucía". Pag. 25.084-25.145. In: BOJA, núm. 154, de 31 de diciembre de 2002. Sevilla: Junta de Andalucía.

JUNTA DE ANDALUCÍA (2006). Plan de Ordenación del Territorio de Andalucía. Sevilla: Consejería de Medio Ambiente y Ordenación del Territorio, Junta de Andalucía.

JUNTA DE ANDALUCÍA (2007). "Ley 14/2007, de 26 de noviembre, del Patrimonio Histórico de Andalucía". Pag. 6-28.
In: BOJA, núm. 248, de 19 de diciembre de 2007. Sevilla: Junta de Andalucía.

JUNTA DE ANDALUCÍA. (1991). "Ley 1/1991, de 3 de julio, de Patrimonio Histórico de Andalucía". Pag. 5573-5586. In: BOJA, núm. 59, de 13 de julio de 1991. Sevilla: Junta de Andalucía.

JUNTA DE ANDALUCÍA. (2019). “Consulta de planes urbanísticos y territoriales de Andalucía", en SITU@ Difusión de la Consejería de Medio Ambiente y Ordenación del Territorio de Andalucía. Online: http://ws041.juntadeandalucia.es/medioambiente/ situadifusion/pages/search.jsf [consult: 19th October 2019]

KRELLENBERG, K., WELZ, J., LINK, F., BARTH, K. (2017). “Urban vulnerability and the contribution of socio-environmental fragmentation: Theoretical and methodological pathways". Progress in Human Geography, 41(4): 408-431. https://doi. org/10.1177/0309132516645959

LANKAO, P. R., QIN, H. (2011). “Conceptualizing urban vulnerability to global climate and environmental change". Current opinion in environmental sustainability, 3(3): 142-149. https://doi. org/10.1016/j.cosust.2010.12.016

LEFEBVRE, H. (1968). Le droit à la ville (Vol. 3). Anthropos: Paris.

LEVRON, E. (2010). Identification of Vulnerable People in Urban Environments: Assessment of Sustainable Livelihoods and Urban Vulnerabilities. Palaiseau: Action Contre la Faim International.

LLOP TORNÉ, J. M., HOEFLICH DE DUQUE, S. (2010). Ciudades intermedias. Barcelona: Secretariado de la Red Mundial de Ciudades y Gobiernos Locales Unidos.

LÖSCH, A. (1940). The Spatial Organization of the Economy. London: Encyclopædia Britannica

MADOZ, P. (1846-1850). Diccionario Geográfico Estadístico Histórico de España y sus posesiones de Ultramar. Madrid.

MATESANZ PARELLADA, Á. (2017). Políticas urbanas y vulnerabilidad. Tesis Doctoral. Universidad Politécnica de Madrid.

MATESANZ PARELLADA, Á. (2018). “Evolución de los parámetros del enfoque integrado en las políticas de regeneración urbana en los barrios vulnerables en España". Gestión y Análisis de Políticas Públicas, 20: 82-99. https://doi.org/10.24965/gapp.v0i20.10488

MERINERO RODRÍGUEZ, R., LARA DE VICENTE, F. (2010). Las Ciudades Medias del interior de Andalucía. Caracterización y retos para el desarrollo turístico en un nuevo entorno. Córdoba: Aecit.

MINISTERIO DE FOMENTO. (2012). Análisis urbanístico de Barrios Vulnerables en España Sobre la Vulnerabilidad Urbana. Madrid: Ministerio de Fomento. Gobierno de España.

MINISTERIO DE FOMENTO. (2015). Atlas de la Vulnerabilidad Urbana en España 2001 y 2011. Metodología, contenidos y créditos. Madrid: Ministerio de Fomento. Gobierno de España. 
NAVAS-CARRILLO, D., PÉREZ CANO, M.T., DEL ESPINO HIDALGO, B., ROYO NARANJO, L. (2019). "Dualidad Turística Residencial de las ciudades medias del litoral andaluz". In: TOURISCAPE, Turismo y Paisaje, pp. 247- 260. Madrid: Tirant Lo Blanch.

NAVAS-CARRILLO, D.; ROSA-JIMÉNEZ, C., PÉREZ CANO, M. T. (2016). Between Historic Sites and New Tourist Destinations: The Development of the First Periphery in Medium-Sized Andalusian Coastal Cities. https://doi.org/10.30958/ajt.3.4.3.

PATEL, R., SANDERSON, D., SITKO, P., DE BOER, J. (2020). "Investigating urban vulnerability and resilience: a call for applied integrated research to reshape the political economy of decision-making". Environment and Urbanization. First published Online. https://doi.org/10.1177/0956247820909275

PERROUX, F. (1955). "Note sur la notion de poles croissance". Économic Appliquée, 8: 307-320.

RAN, J., MACGILLIVRAY, B. H., GONG, Y., HALES, T. C. (2020). “The application of frameworks for measuring social vulnerability and resilience to geophysical hazards within developing countries: A systematic review and narrative synthesis". Science of The Total Environment, 711 (134486): 1:16. https://doi.org/10.1016/j. scitotenv.2019.134486

RODRÍGUEZ PEÑA, V. (2017). Análisis de la vulnerabilidad social-urbana en Valladolid:Una aproximación Geográfica. Universidad deValladolid.

RUIZ, A. (2019). "El potencial de la percepción social aplicada al análisis de la vulnerabilidad en planificación urbana". EURE. Revista De Estudios Urbano Regionales, 45(136): 31-50. http:// dx.doi.org/10.4067/S0250-71612019000300031

RUIZ CASTILLO, J. (2004). “Los fundamentos de la protección: el efecto desintegrador producido por la consideración del Patrimonio Histórico como factor de desarrollo". Patrimonio cultural y derecho, 8: 11-36.

SINGH, C., DESHPANDE T., BASU, R. (2017). "How do we assess vulnerability to climate change in India? A systematic review of literature". Regional Environmental Change, 17: 527-538. https:// doi.org/10.1007/s10113-016-1043-y

TEMES, R. (2014). "Valoración de la vulnerabilidad integral en las áreas residenciales de Madrid". EURE. Revista De Estudios Urbano Regionales, 40(119): 119-149. http://dx.doi.org/10.4067/S0250$\underline{71612014000100006}$

TWIGG, J. (2015). Disaster Risk Reduction. London: Overseas Development Institute

UNESCO. (2003). “Renaissance Monumental Ensembles of Úbeda and Baeza". In: Decisions adopted by the 27th sesión of the World Heritage Committee. Paris: UNESCO.

UNESCO. (2016). "Antequera Dolmens Site". In: Report of the decisions adopted during the 40th session of the World Heritage Committee. Istanbul: UNESCO.
UNESCO. (2018). Re|shaping cultural policies: advancing creativity for development. Online: https://unesdoc.unesco.org/ark:/48223/ pf0000260678 [consult: 19th October 2019]

UNITED NATIONS. (2013). Report on the world social situation, 2003. Social Vulnerability: Sources and Challenges. New York: United Nations Reproduction Section.

VILAGRASA, J. (2000). Ciudades medias y ciudades intermedias: posicionamiento en la red urbana y procesos urbanos recientes. Online: http://www etsav.upc.es/personals/monclus/cursos/ ibarz.htm [consult: 19th October 2019]

WEICHSELGARNTER, J. (2001) "Disaster mitigation: The concept of vulnerability revisited". Disaster Prevention and Management: An International Journal 10: 85-95.

WISNER, B., BLAIKIE P., CANNON, T., DAVIS, I, (2004). At Risk: Natural Hazards, People's Vulnerability and Disasters. London: Routledge.

\section{Author/s}

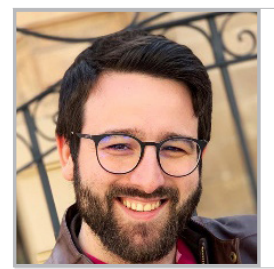

\section{Daniel Navas-Carrillo}

dnavas@us.es

University of Seville (Spain

Is a PhD Researcher at the Urban and Regional Planning Department of the University of Seville (Spain). He holds a PhD in Architecture (2020), a MSC in Heritage and Architecture (2017) and a MSc in Innovation in Architecture (2016). His research aims to analyse the urban growth experienced in the third quarter of the 20th century in medium-sized cities from a heritage perspective. He has received several prizes such as the Urbanism and Architecture Biennale Research Award (2016) and the Young Researcher TechnoHeritage Award (2019).

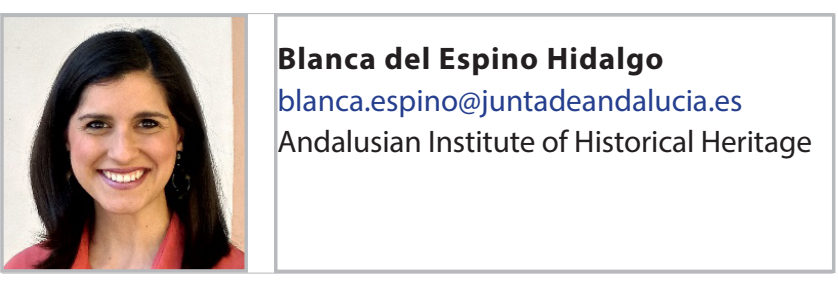

Is a full-time PhD Researcher at the Andalusian Institute of Historical Heritage, Centre of Built Heritage, Department of Projects. She holds a PhD in Architecture (2015), a MSC in Heritage and Architecture (2011) and a MSC in Sustainable Cities and Architecture (2013). She has been a pre-doctoral and post-doctoral researcher and assistant professor at the University of Seville (Spain). Her research is focused on cultural heritage sustainability, mainly on urban and territorial dimensions, including landscape and social components. 


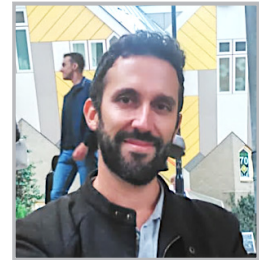

Juan-Andrés Rodríguez-Lora

jrodriguez91@us.es

University of Seville (Spain)

Predoctoral Researcher at the Urban and Regional Planning Department of the University of Seville (Spain). He holds a Degree in Architecture (2016), a MSc in Heritage and Architecture (2018) and is currently studying a MSc in Urbanism, Urban Planning and Urban Design (2020). His research focuses on contemporary heritage preservation from an urban perspective. He has received several awards, such as the Extraordinary Degree Award (2016).

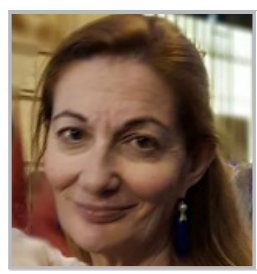

\section{Teresa Pérez-Cano}

tpcano@us.es

University of Seville (Spain)

Is a full-time Professor at the Urban and Regional Planning Department of the University of Seville (Spain) since 1995. Permanently collaborating with several Master and Doctorate programmes, she has been the director of more than 29 doctoral theses. Co-founder and director of the research group HUM-700 Heritage and Urban and Territorial Development in Andalusia. Focused on urban planning preservation, the group has conducted several types of research, urban plans, and professional advisory on classed buildings, monuments, historic centres, and landscapes. She has leaded several R\&D projects on medium-sized cities in Andalusia

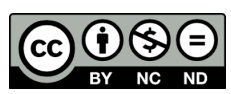

https://doi.org/10.37558/gec.v17i1.754 